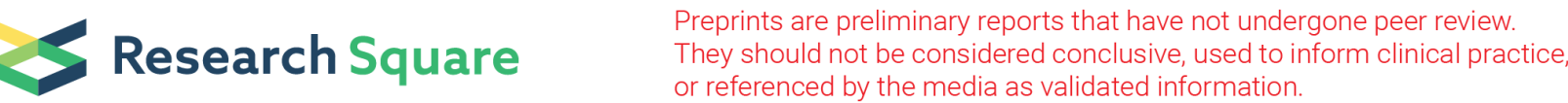

\section{Special Behavior of Homo(eo)logous Chromosomes at Meiosis and the Mechanism of Partial Female Fertility of Allotriploid Lilium 'triumphator' (LLO)}

Luomin Cui

Jiangxi Agricultural University

Yanni Sun

Jiangxi Agricultural University

Kongzhong Xiao

Jiangxi Agricultural University

Lin Wan

Jiangxi Agricultural University

Ju Zhong

Jiangxi Agricultural University

Yanmei Liu

Jiangxi Agricultural University

Shujun Zhou ( $\nabla$ zhou2014@jxau.edu.cn )

Jiangxi Agricultural University https://orcid.org/0000-0001-8627-291X

Research article

Keywords: Interploid hybridization, Fritillaria embryo sac, Polygonum embryo sac, Aneuploid, Euploid, Meiosis

Posted Date: November 13th, 2020

DOI: https://doi.org/10.21203/rs.3.rs-104834/v1

License: (a) (1) This work is licensed under a Creative Commons Attribution 4.0 International License. Read Full License 


\section{Abstract}

Background: The abnormal meiosis of triploid is paid little attention; however, triploid not only is an important trend of ornamental breeding but also is regarded as a bridge of plant polyploidy speciation. In the present research, an allotriploid lily 'Triumphator' (LLO, $2 n=3 x=36$ ) was investigated.

Results: The results showed that the homoeologous chromosomes of two L-genomes formed bivalents and then disjoined and their half-bivalents moved to opposite poles at anaphase l; The chromosomes of o-genome formed univalents, among which, some attached to spindle fibers on two sides, their sister chromtids moved to the opposite poles slower than half-bivalents; some attached to spindle fibers on one side, they move to one pole at similar speed to half-bivalents; some of which deattached to spindle fibers at kinechores on either side, they became micronuclei at anaphase I.

Conclusions: Interploid hybridizaitons showed that the LLO lily, regarless of male sterile, could be female parents to crossed with appropriate males to produce aneuploids, supporting the hypothesis - five same genomes is essential for its endosperm development in interploid hybridizations of Lilium. The discussion well not only explained why triploid lilies with Fritillaria embryo sacs, regardless of male sterile, are usually partial female fertile while other plants with polygonum embryo sacs are seedless; but also explained that why $3 x \times 2 x / 4 x$ lilies and tulips produce predominantly aneuploids while $3 x \times 2 x / 4 x$ and $2 x / 4 x \times 3 x$ of other plants, including $2 x / 4 x \times 3 x$ of lilies and tulips, produce euploids and near so.

\section{Background}

Triploid, containing three sets of chromosomes, is usually sterile and seedless. It is often regarded as bottle neck for introgression breeding due to its sterility, especially for field crops which are propagated usually by sowing seeds; however, triploid has been used to breed seedless watermelon [1], banana [2], grape [3], Citrus [4], and many ornamental crops, like tulip and lily [5, 6], because they can be propagated through cutting, grafting or tissue culture. In addition, tripoid is regarded as a bridge to polyploidy speciation naturally $[7,8]$. Since $2 n$ gametes occur popularly in plants with very low rate [9], the possibility of unilateral sexual polyploidization is much higher that bilateral sexual polyploidization, i.e., triploid is first formed much easier than tetraploid [7]. Actually, not all triploids are completely sterile. Once partially fertile triploids have been formed, they could produce not only auepoloid, but also euploids like tetraploids, pentaploids, and hexaploids through $3 x \times 2 x, 2 x \times 3 x, 3 x \times 3 x$, and then, may produce $4 x, 5 x$, etc., by $3 x \times 4 x$, and then other ploidy level popluations through more interploidy hybidization $[7,10]$. Thus, triploids play important roles in plant polyploidy speciation.

Allotriploid lilies are a main trend of modern lily breeding. They are obtained from $\mathrm{BC}_{1}$ progeny of distant interspecific $\mathrm{F} 1$ hybrids, because such $\mathrm{F} 1$ hybrids can produce small amount of functional $2 n$ gametes and nonfunctional aueploid or $\mathrm{n}$ gametes due to abnormal meiosis [11-21]. In some cases, the sterile F1 hybrids were induced to become allotetraploid using oryzalin and colchicine to restore their fertility [22], 
then allotriploids are obtained through $4 x \times 2 x$ or $2 x \times 4 x$ [19]. So far, most lily intersectional cultivars are allotriploid [5, 23].

Triploid lilies have special characteristics on their fertility. Different from that other triploid plants are usually highly sterile both male and female as well, for example, seedless watermelon, grape, banana, mandarin, and others, triploids lilies are partial female fertile regardless of completely male sterile, i.e., they can be used female parents to cross with appropriate diploid/tetraploid to predominantly produce aneuploid progeny [24-26]. The phenomena are well explained by analysis the characteristics of different megasporogenesis and their significance on the success/failure of $3 x \times 2 x / 4 x$ crosses between Fritillariatype and Polygonum-type plants (See detail in discussion).

Meiosis is the key step in the sexual life cycle, not only for species to continue from generation to generation and but also for species to evolve others, because it is the basis of heritage, mutation, assortment, and recombination [27]. However, there is very little attention paid on abnormal meiosis of triploids. The reasons for that, probably, are 1) it is hard to obtain triploid; 2) triploid can't perpetuate sexually because they are usually sterile and seedless, and thus not so valulable for field crops. Since triploid is important for plant polyploidy speication and triploid lilies are very popular and good materials for cytogenetic study, we investigated the microsporogenesis of an allotriploid lily, analyzed its male and female fertility, and the genomic composition of its progeny, and then, discussed its significance on lily breeding and plant speciation.

\section{Results}

\section{The microsporogenesis}

As lily breeder claimed, GISH showed that 'Triumphator' has two sets of L-genomes and one set of Ogenome, i.e., an allotriploid (LLO, $2 n=3 x=36$ ) (Fig. 1a). The allotriploid lily displayed the characteristics. 1) At metaphase I (Fig. 1 b and c), the homologous chromosomes of two L-genomes usually associated to form bivalents (white "II"), while their homoeologous chromosomes of one 0-genome remained univavent (red "I"); In a few cases, bivalents were formed by one 0-genome (Fig. 1b: red "II") or by L- and O-genomes (Fig. 1b: red"I" + white "I"), multivalents formed by either L-genome (Fig. 1b and c: III and IV) or L- and 0-genomes (Fig. 1b: white "II" + red "I") were also observed; sometimes, multivalents might not be true, just because two bivalents, or one univalent and one bivalent, adjoined by chance. 2) At anaphase I (Fig. 1d, e and f), the bivalents were disjoined and moved to the two opposite poles (Fig. 1d, e and $\mathrm{f}: \mathbb{\nabla})$ while some univalents stayed on the equatorial plates $(\mathbb{\nabla})$, possibly because spindle fibers exerted equal opposite forces on the kinetochores on the bivalents and the univalents, but bivalents need less force to separate than univalents; However, some L-chromosomes $(\mathbb{\nabla})$ moved seemingly to the poles faster than L-chromsomes $(\mathbb{\nabla})$, possibly because the 0 -chromosomes never attached to spindle fibers and they just stayed there occasionally; and there are a few 0-chromosomes ( $\mathbb{\nabla})$ which moves the same as half-bivalent ( () , possibly because one side of them were attached with spindle fiber. Besides, in most PMCs, some 0-chromosomes were apparently missing. It was not certain that they were really degraded 
or a few chromosomes might be associated together. The mechanism needs further and elaborate work.

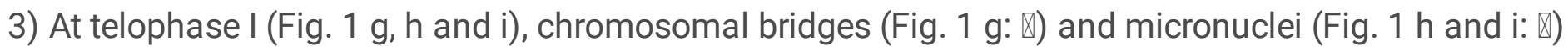
were commonly seen at this stage. The former might be caused by multiple crossovers, the latter might be due to detachment to spindle microtubule polymer due to the dysfunctional kinechores. At this stage, the PMCs with such abnormal phenomenon were take account 43.3\%. 4) At anaphase II and telophase II (Fig. $1 \mathrm{j}$, $\mathrm{k}$ and I), chromosomal bridges could be seen in 12.2\% of PMCs; Most PMCs produced tetrad, while $3.9 \%$ produce triad. Based on observation of microsporogenesis, it was concluded that the LLO lily had abnormal meiosis.

Here we summarize the abnormal behaviour of chromosomes of LLO lily with an ideogram (Fig. 2). Homoeologous chromosomes of two L-genomes formed bivalents and their two sides attached to spindle fibers (microtubule polymers) at anaphase I, then disjoined and half-bivalents moved to opposite poles at anaphase I (Fig. 2: 区); One O-genome chromosomes form univalents, some of which attached to spindle fibers at kinechores on two sides, and sister chromotids move to the opposite poles slower than half-bivalents (Fig. 2: 『); some of which attached to spindle fibers at kinechores on one side, they move to one pole at similar speed to half-bivalents (Fig. 2: $邓$ ); some of which deattached to spindle fibers at kinechores on either side, they became micronuclei at anaphase I (Fig. 2: 『) .

\section{Male and female fertility of LLO}

In vitro pollen germination test showed that no pollen grains of triploid LLO germinated and the other diploid lilies were 33.5-67.50\% (Table 1). Though the LLO was completely male sterile; however, when it was hybridized with LL, TT and 00 using normal pollination respectively. Their fruits of all combinations developed to different extents (Table 2, Fig. 3). Obviously, the fruits of LLO $\times$ LL /TT developed better than those of LLO $\times 00$. Seemingly, the fruits of LLO $\times$ LL were similar to those of LLO $\times$ TT; however, the ovules in the fruits of LLO $\times$ LL developed much better than those of LLO $\times$ TT and LLO $\times 00$, because some embryos or endosperm could be isolated from LLO $\times$ LL. 14 seedlings were obtained from LLO $\times$ LL, and only callus were from LLO $\times$ TT /OO (Fig. 2). It was concluded that LLO could be female parents to hybridize with appropriate diploid males.

Table 1 The genome composition (GC), chromosome number (Ch No.), and pollen germination (PG) of lilies

\begin{tabular}{|llll|}
\hline Lily & GC & Ch No. & PG (\%) \\
\hline Triumphator & LLO & $2 n=3 x=36$ & 0 \\
\hline White fox & LL & $2 n=2 x=24$ & $33.51 \pm 3.67$ \\
\hline L. regale & TT & $2 n=2 x=24$ & $42.96 \pm 4.89$ \\
\hline Sorbonne & OO & $2 n=2 x=24$ & $67.50 \pm 4.33$ \\
\hline
\end{tabular}


Table 2 The crosses and their pollinated flowers, rescued fruits, developed ovules, isolated embryos, and survival seedlings

\begin{tabular}{|llllllll|}
\hline Code & Female & Male & Flowers & Fruits & Ovules & Embryos & Seedlings \\
\hline 1 & LLO & LL & 56 & 20 & 294 & 5 & 14 \\
\hline 2 & LLO & TT & 15 & 10 & 76 & 0 & 0 \\
\hline 3 & LLO & OO & 42 & 19 & 181 & 0 & 0 \\
\hline
\end{tabular}

\section{Genomic composition of the progeny}

Nine seedlings of LLO $\times$ LL were analyzed using GISH. The results showed that they were aneuploid, with chromosome number ranging from 27-32 (Fig. 4 and Table 3). All of them contained 24 L-chromosomes, indicating 12 of them were from LLO because LL contributed 12 L-chromosomes, and had Ochromosomes from three to eight. In addition, no recombinant chromosomes were found in the progeny. Because the homologous chromosomes of two L-geomes usually form bivalents (II) and their homoeologous chromosomes of one O-genome remained univavent (I) in most PMCs of LLO, it was expected that their gametes should contain $12 \mathrm{~L}$-chromosomes and variable 0-chromosomes from such abnormal meiosis. The genomic compositions of the progeny were agreeable to the chromosomal behaviors during meiosis.

Table 3 Genome compositions of 9 seedlings of LLO $\times$ LL based on GISH analysis, indicating their chromosome numbers (Ch No.) including L-chromosome numbers (L-No.) and O-chromosome numbers (O-No.), and the chromosome numbers contributed by pollen (No. by Pollen) and those by egg (No. by Egg) 


\begin{tabular}{|llllll|}
\hline Seedling code & Ch No. & L-No. & O-No. & No. by Pollen & No. By Egg \\
\hline 1 & 27 & 24 & 3 & 12 & 15 \\
\hline 2 & 32 & 24 & 8 & 12 & 20 \\
\hline 4 & 29 & 24 & 5 & 12 & 17 \\
\hline 5 & 29 & 24 & 5 & 12 & 17 \\
\hline 6 & 30 & 24 & 6 & 12 & 18 \\
\hline 7 & 28 & 24 & 4 & 12 & 16 \\
\hline 10 & 28 & 24 & 4 & 12 & 16 \\
\hline 11 & 30 & 24 & 6 & 12 & 18 \\
\hline 12 & 31 & 24 & 7 & 12 & 19 \\
\hline Average & 29.3 & 24 & 5.3 & 12 & 17.3 \\
\hline
\end{tabular}

\section{Discussion}

There are very a few reports on meiosis of allotriploid lily. For example, 'Cocossa' (OOT) is partial male fertile and micronuclei are obviously observed at telophase of its abnormal meiosis [28]. The same phenomenon occurs in the present research (Fig. 1h and i). Micronuclei are common in human cancerous cells and they possibly arise from hypomethylation of repeat sequences in pericentromeric DNA, irregularities in kinetochores, dysfunctional spindle apparatus, or flawed anaphase checkpoint genes [29]. When allotriploid LLO meiosis is compared with distant diploid LA F1 hybrids [21], we notice both LLO and LA have form bivalents and univalent at metaphase I; however they show different chromosome behaviour at anaphase I: in LA hybrids, both bivalents and univalents are separated and pulled to the opposite poles [21]; while in LLO, bivalents are disjoined and move to the opposite pole, some univalents are scattered irregularly. Since the chromosomal movement at anaphase in normal meiosis is caused by microtubulin polymerdegrade [30,31], we speculate that the bivalents in LLO attach the spindle microtubule polymer the same as in normal meiosis; however, some univalents attach the spindle microtubules on either or both of their two sides; some univalents do not detach to any spindle microtubule (Fig. 2).

Although triploid lilies have abnormal meiosis and are usually male sterile, however, they are partially female fertile. They can be used as female parents to cross with appropriate diploid/tetraploid to predominantly produce aneuploid progeny (Table 4, Fig. 5a). Lilium have Fritillaria embryo sac [32]. In Fritillaria embryo sacs, the ploidy levels of the secondary nucleus do not vary with the egg cell $[19,24,26]$ and constantly twice as somatic cell. For an example: the allotriploid lily 'Triumphytor' (LLO) in the present research produce aneuploid egg cells due to abnormal meiosis but its secondary nuclei are 
constantly hexploid $(6 \mathrm{x}=4 \mathrm{~L}+20)$. So, In lily $3 x \times 2 x / 4 x$, the embryos are usually aneuploid while the endosperm of $3 x \times 2 x$ is $7 x$ and that of $3 x \times 4 x$ is $8 x$ (Fig. 6: b1, b2). Since euploid endosperm could develop due to balanced chromosomes, some aneuploid embryos in the lily $3 x \times 2 x / 4 x$ crosses can survive [26]. Based on Table 4, it is observed that the endosperm with $\geq 5$ same genomes developed well and the crosses are highly successful, while the endosperm with $<5$ same genomes usually aborted and the crosses were usually unsuccessful. Considering that endosperm of normal $2 x \times 2 x$ crosses contain 5 same genomes in Lilium, the hypothesis - Five Same Genomes of Endosperm is Essential for its Development in interploid hybridizations of Lilium, has been proposed to explain the partial female fertility of triploid lilies [24]. Because LLO $\times$ LL, whose endosperm genome composition (EGC) is $5 \mathrm{~L}+20$, is successful while LLO $\times 00 / T T$, whose EGC is $4 \mathrm{~L}+30 / 4 \mathrm{~L}+20+\mathrm{T}$, are hard successful, the present results support the hypothesis. So far, however, there are three exceptions for the hypothesis, LLO $\times$ TTTT, LLO $\times$ OTOT [33] and LLO $\times$ AA [34]. Possibly, genomic imprinting, i.e., an excess dosage of paternal genomes promotes endosperm development $[35,36]$, is the reason why LAA (AAA) $\times$ AAAA is more successful than LAA (AAA) $\times$ AA in Lilium [24]. Similarly, a paternal T-genome in the endosperm of LLO $\times$ TTTT more than of LLO $\times$ TT is beneficial to its success, even a paternal O-genome in the endosperm of LLO $\times$ OTOT more than of LLO $\times$ TT is also good for the endosperm development. LLO $\times$ AA is very special exception; however, it does not mean that its endomsperm develop as well as the endosperm of LLO $\times$ LL, because a very few seedlings are obtained from a large amount of cultured ovules rather than cultured embryo sacs or embryos. The best way to solve the problem would be to use LLO as female to hybridize with LL, OO, TT, AA, LTLT, OTOT, OAOA as males to compare their success or failure in one season and on same site. Anyhow, it is concluded that triploid lilies can be used female parents to cross with appropriate diploid or tetraploid males to produce aneuploids regardless of male sterility. The hypothesis not only explain well the suceess or failure of $3 x \times 2 x / 4 x$ crosses, but also can guide breeders to combine to different genomes into one cultivar step by step. For example, we may combine $L-, A-, T-$ and $O$ with LALA, LOLO and TATA through the following two steps:

- $L A L A \times O A O A \rightarrow(L A O A) * *$

- $L A O A \times$ TATA $\rightarrow$ L*ATAO*

or

- LALA $\times$ TATA $\rightarrow($ LATA $) \star *$

- $L A T A \times O A O A \rightarrow L^{*} A T * O A$

(note: $L^{\star}, O^{\star}$ and $T^{\star}$ means that their genomes are not complete because (LAOA)** and (LATA)** have abnormal meiosis and produce aneuploid gametes).

Tulip and Fritillaria also important Fritillaria-type plants. Triploid tulips also can be female parents to cross with diploid or tetraploid males [37-39]. Firitillaria is an important medicinal herb. It is expected $3 x \times$ $2 x / 4 x$ can produce aueuploid Fritillaria, the variations caused by aneuploid would be good chance to select new varieties containing higher amount of effective chemicals. 
Unlike lilies, Tulips, and Fritillaria with Frititillaria-type embryo sacs, most plants, like watermelon and banana, produce Polygonum embryo sacs. Their triploids are usually male and and female sterile. Once they have partially male and female fertility, the $3 x \times 2 x / 4 x$ or $2 x / 4 x \times 3 x$ crosses produced more euploids or near euploids than other aneuploids as illustrated in Fig. 5. This phenomenon could be explained with their monosporic embryo sacs. Based on normal megasporogenesis, it is deduced that the ploidy levels of the secondary nucleus in Polygonum embryo sacs are invariably twice as that of the egg cell. So, whether in the $3 x \times 2 x / 4 x$ or $2 x / 4 x \times 3 x$ crosses, both the embryos and endosperm are usually aneuploid (Fig. 6. b3, b4, c3 and c4 ); since aneuploids are little viable due to unbalanced genes, these triploids are usually seedless; only when some triploids have partially female or male fertility, $3 x \times 2 x / 4 x$ or $2 x / 4 x \times 3 x$ crosses can produce some euploids and or near so due to inter-embryo competition [10].

If triploid lilies and tulips have partially male fertile, $2 x / 4 x \times 3 x$ produce also produce more euploids or near euploids than other aneuploid (Fig. 5b), which are similar to other $2 x / 4 x \times 3 x$ and $3 x \times 2 x / 4 x$ crosses in polygonum-type plants (Fig. $5 \mathrm{c}$ and d). This is because both embryos and endosperm of $2 x / 4 x \times 3 x$ in Lilium are aneuploid (Fig. $6 \mathrm{c} 1$ and c2) similar to other $2 x / 4 x \times 3 x$ and $3 x \times 2 x / 4 x$ crosses in polygonumtype plants (Fig. 6. b3, b4, c3 and c4).

Triploid is not only the source to produce aneuploid varieties but also is the bridge in plant polyploidy speciation. In angiosperms, 40-70\% of them have been identified as polyploids [40]. Though polyploidy mechanisms include bi-sexual polyploidisation, uni-sexual polyploidisation and chromosome doubling, it is increasingly accepted that the $2 n$ gamete is the main reason for polyploid speciation $[9,41]$. The occurrence of bi-sexual polyploidisation and chromosome doubling is much rarer than uni-sexual polyploidisation, indicating that a triploid resulting from uni-sexual polyploidisation may act as a bridge role in polyploid speciation [7, 41, 42]. As analyzed in Fig. 6, once triploids are formed in Polygonum-type plants, $3 x \times 2 x$ or $2 x \times 3 x$ possibly produce diploid, triploid, and even tetraploid or pentaploid though the possibility is rare. $3 x \times 3 x$ also possibly produce different ploidy level populations, but it is more rarer because there is very little chance for very few functional pollen grains to meet very few functional eggs in this combination. Since aneupolids are poor viable and they could not perpetuate sexually, then, during the process of polypoloidy speciation with triploid as a bridge, their basic chromosome numbers usually remain unchanged in different ploidy level taxa. Different from Polygonum-type plants, once triploids occur in Fritillaria-type plants, $3 x \times 2 x$ can produce lots of aneploids with quite variable chromosome numbers. If they can be propagated asexually, many new species with different basic chromosome numbers might be formed after adaptation and evolution. Limonium $(2 n=12,14,16,24$, and 36$)$ of Plumbaginaceae, also an tetrasporic-type plant, is good example [43] for this point. However, this is the first time to propose the relationship between the embryo sac type and the basic chromosome number during angiosperm speciation. It needs further elaborate and extensive work unveil the complex mechanism.

Table 4. The summary of reported $3 x \times 2 x / 4 x$ of Lilium, indicating the interploid crosses are usually successful when their endosperm contain $\geq 5$ same genomes 


\begin{tabular}{|c|c|c|c|c|c|}
\hline \multirow{2}{*}{$\begin{array}{l}\text { Interploidy } \\
\text { hybridization }\end{array}$} & \multicolumn{3}{|c|}{ Genome composition of } & \multirow{2}{*}{$\begin{array}{l}\text { Cross } \\
\text { ability }\end{array}$} & \multirow[t]{2}{*}{ Reference } \\
\hline & $\begin{array}{l}\text { Secondary } \\
\text { nucleus }\end{array}$ & Sperm & Endosperm & & \\
\hline $\mathrm{LAA} \times \mathrm{AA}$ & $4 A+2 L$ & A & $5 A+2 L$ & $++/-$ & [44] \\
\hline LAA $\times$ LALA & $4 A+2 L$ & $L+A$ & $5 A+3 L$ & + & [44] \\
\hline$L A A \times L A$ & $4 A+2 L$ & $\begin{array}{l}(\mathrm{L}+ \\
\text { A) } 1\end{array}$ & $5 A+3 L$ & + & [45] \\
\hline $\mathrm{LAA} \times 00$ & $4 A+2 L$ & 0 & $4 A+2 L+0$ & - & [24] \\
\hline$L A A \times L L$ & $4 A+2 L$ & L & $4 A+3 L$ & - & [24] \\
\hline $\mathrm{LAA} \times \mathrm{AA}$ & $4 A+2 L$ & $A$ & $5 A+2 L$ & + & [24] \\
\hline LAA $\times$ AAAA & $4 A+2 L$ & $2 \mathrm{~A}$ & $6 A+2 L$ & ++ & [24] \\
\hline $\mathrm{LAA} \times \mathrm{AA}$ & $4 A+2 L$ & A & $5 A+2 L$ & + & [46] \\
\hline LAA $\times$ AAAA & $4 A+2 L$ & AA & $6 A+2 L$ & ++ & [46] \\
\hline$A A A \times A A$ & $6 \mathrm{~A}$ & A & $7 \mathrm{~A}$ & + & [26] \\
\hline AAA $\times$ AAAA & $6 \mathrm{~A}$ & $2 \mathrm{~A}$ & $8 \mathrm{~A}$ & ++ & [26] \\
\hline$A A A \times A A$ & $6 \mathrm{~A}$ & A & $7 \mathrm{~A}$ & + & [47] \\
\hline$A O A \times A A$ & $4 A+20$ & A & $5 A+20$ & + & [48] \\
\hline$A O A \times O A$ & $4 A+20$ & $\begin{array}{l}(0+ \\
A)^{1}\end{array}$ & $5 A+30$ & + & [48] \\
\hline$A O A \times O A O A$ & $4 A+20$ & $O+A$ & $5 A+30$ & + & [48] \\
\hline$A O A \times A A$ & $4 A+20$ & $A$ & $5 A+20$ & + & [45] \\
\hline ОТО $\times 00$ & $40+2 T$ & 0 & $50+2 T$ & + & [49] \\
\hline ОТО $\times 00$ & $40+2 T$ & 0 & $50+2 T$ & + & [25] \\
\hline ОTO $\times$ TT & $40+2 T$ & $\mathrm{~T}$ & $40+3 T$ & - & [25] \\
\hline LLO $\times$ LLTT & $4 \mathrm{~L}+20$ & $L+T$ & $5 L+20+T$ & + & [50] \\
\hline LLO $\times$ TTTT $^{2}$ & $4 L+20$ & $2 T$ & $\begin{array}{l}4 \mathrm{~L}+20+ \\
2 \mathrm{~T}\end{array}$ & + & [33] \\
\hline LLO $\times$ OTOT $^{2}$ & $4 L+20$ & $0+T$ & $4 L+30+T$ & + & [33] \\
\hline $\mathrm{LLO} \times \mathrm{AA}^{2}$ & $4 L+20$ & A & $4 L+20+A$ & + & [34] \\
\hline $\mathrm{OHO} \times \mathrm{OO}$ & $4 \mathrm{O}+2 \mathrm{H}$ & 0 & $5 \mathrm{O}+2 \mathrm{H}$ & + & [18] \\
\hline $\mathrm{OHO} \times \mathrm{HH}$ & $4 \mathrm{O}+2 \mathrm{H}$ & $\mathrm{H}$ & $4 \mathrm{O}+3 \mathrm{H}$ & - & [18] \\
\hline
\end{tabular}




\begin{tabular}{|llllll|}
\hline$M A A \times A A$ & $4 A+2 M$ & $A$ & $5 A+2 M$ & + & {$[33]$} \\
$M A A \times A A A A$ & $4 A+2 M$ & $2 A$ & $6 A+2 M$ & + & {$[33]$} \\
\hline
\end{tabular}

A-Asiatic; L-Longiflorum; 0 - Oriental; T - Trumpet; $\mathrm{H}$-Lilium henryi; $\mathbf{M}$-L. martagon

1 indicating the male produce $2 n$ pollen; ${ }^{2}$ indicating three successful $3 x \times 2 x / 4 x$ hybridizations without 5 sames genomes in their endosperm.

\section{Conclusions}

The present study and above discussion prove that all triploid lilies are partially female fertile regardless of their complete male sterility because they are tetrasporic-type plants, and then can be used to cross with appropriate diploid or tetraploid males to breed aneuploid cultivars; The hypothesis, Five Same Genomes of Endosperm is Essential for its Development in $3 x \times 2 x / 4 x$ crosses in Lilium, can guide breeders to select parents to successful combine different genomes in lily or even other tetrasporic-type plant breeding; Possibly, the embryo sac plays some roles in the change of basic chromosome numbers during plant speciation. In addition, the abnormal chromosome behavior at anaphase I would give a new way to unveil the molecular mechanism of the microcuble disassembly and chromosomal movements.

\section{Methods}

\section{Plant materials}

In order to analyze the characteristics of meiosis and fertility of allotriploid lilies, three lilies cultivars, 'Triumphator' (LLO, $2 n=3 x=36$ ), 'White fox' (LL, $2 n=2 x=24)$, and 'Sorbonne' (OO, $2 n=2 x=24)$, and one speices, $L$. regale Wilson (TT, $2 n=2 x=24)$ were used in the present study. All lily plants were grown in the Jiangxi Agricultural University, China.

\section{Microsporogenesis}

Microsporogenesis was according to Zhou et al. [21]. When flower buds were about 27-38 $\mathrm{mm}$, their anthers were taken out and put in a vial containing a Carnoy's solution (ethanol: acetic acid $=3: 1, \mathrm{~V} / \mathrm{V}$ ) and stored for at least $30 \mathrm{~min}$. Then, some pollen mother cells (PMCs) were put on slides and mixed with a drop of $2 \%$ Carbol Fuchsin (Beijing Solarbio Science \& Technology Co. Ltd. ), and the slides were immediately covered with square covers and checked under a microscope (ZEISS Scope. A1).

\section{Pollen germination}

Pollen germination was according to Zhou et al. [21]. The fresh pollen grains were scattered on a medium containing $100 \mathrm{~g} / \mathrm{L}$ sucrose, $5 \mathrm{~g} / \mathrm{L}$ bacteriological agar, $20 \mathrm{mg} / \mathrm{L} \mathrm{H}_{3} \mathrm{BO}_{3}$, and $200 \mathrm{mg} / \mathrm{L} \mathrm{Ca}\left(\mathrm{NO}_{3}\right)_{2}$ at pH 5.8. All the chemicals were bought from Shanghai Sinopharm Chemical Reagent Co. Ltd. Pollen germination was observed under a stereomicroscope (Nikon C-LEDs). 


\section{Pollination and embryo rescue}

The pollination and embryo rescue according to Zhou et al. [26]. When LLO flowers were near open, their anthers were removed and were pollinated with the pollen of LL, TT and 00 respectively, using normal pollination. All the pollinated stigma were wrapped with aluminum. When the fruits become soft, they were harvested for embryo rescue. The embryo sacs or seeds were put in a medium, containing $2.2 \mathrm{~g} / \mathrm{L}$ MS (Duchefa Biochemie), $60 \mathrm{~g} / \mathrm{L}$ sucrose and $4 \mathrm{~g} / \mathrm{L}$ gelrite (Duchefa Biochemie) and pH 5.8, for $6 \sim 8$ weeks at $25^{\circ} \mathrm{C}$. The seedlings were transferred to medium containing $2.2 \mathrm{~g} / \mathrm{L} \mathrm{MS}, 50 \mathrm{~g} / \mathrm{L}$ sucrose, $3 \mathrm{~g} / \mathrm{L}$ gelrite and $\mathrm{pH} 5.8$, for about 10 weeks at $25^{\circ} \mathrm{C}$ and $2000 \mathrm{~lx}$ light density for 12 hours per day.

\section{Meiotic and mitotic chromosome preparation}

Meiotic chromosome preparation was the same as described in microsorogenesis except that a drop of $2 \%$ Carbol Fuchsin was replace by a drop of $45 \%$ acetic acid. The good slides were selected for GISH analysis. Mitotic chromosome slides were prepared according to Zhou et al.[20] .

\section{Genomic in situ hybridization (GISH)}

GISH was according to Xiao et al. [62] and Yang et al. [63] . 'Sorbonne' DNA as probe was labeled with biotin-11-dUTP (Roche 11745824910). The hybridization mix (40 $\mu \mathrm{L})$ contained $50 \%$ deionized formamide (Applied Biosystems), 10\% dextran sulphate (Beijing Solarbio Science \& Technology Co. Ltd.), $2 \times \operatorname{SSC}(0.3 \mathrm{M} \mathrm{NaCl}$ plus $30 \mathrm{mM}$ Sodium citrate, pH 7.0; Duchefa Biochemie), $0.25 \%$ sodium dodecyl sulfate (Duchefa Biochemie), 25-50 ng probe DNA, 1-3 $\mu$ g block DNA (herring sperm DNA, Beijing Solarbio Science \& Technology Co. Ltd.). Biotin signal was detected with CY-3-conjugated streptavidin (Invitrogen, Camarillo, CA) and biotinylated anti-streptavidin (Vector Laboratories, Burlingame, CA). A drop of Vectashield-1200, containing DAPI (Vector Laboratories, Burlingame, CA) was added and and covered with a glass cover, and the slides were observed using a fluorescence microscope (ZEISS Scope. A1).

\section{Abbreviations}

GISH: Genomic in situ hybridization; PMC: pollen mother cell; EGC: endosperm genome composition

\section{Declarations}

\section{Ethics approval and consent to participate}

'Not applicable'

\section{Consent for publication}

'Not applicable'

\section{Availability of data and materials}


'Not applicable'

\section{Competing interests}

The authors declare that they have no competing interests

Funding: This work was supported by the National Natural Science Foundation of China for financial supports (No. 31572154 and 31460527 ).

\section{Authors' contributions}

L.C.: most investigation, preparation of initial manuscript on materials, methods and results. Y.S.: management of experimental lab and manuscript correction. K.X.:Part of experimental manipulation. L.W.: part of experimental manipulation. J.Z.: part of experimental manipulation. Y.L.: part of experimental manipulation. S.Z.: conceptualization, methodology, and manuscript writing and correction.

\section{Acknowledgements}

'Not applicable'

\section{References}

1. Maynard DN, Elmstrom GW. Triploid watermelon production practices and varieties. Acta Hortic. 1992;318:169-178. https://doi.org/10.17660/ActaHortic.1992.318.21

2. Ortiz R, Ferris RSB, Vuylsteke DR, editors. Banana and plantain breeding. Dordrecht: Springer; 1995. p. 110-146. https://doi.org/10.1007/978-94-011-0737-2_5

3. Hiramatsu M, Wakana A, Park SM, Fukudome I. Production of triploid plants from crosses between diploid and tetraploid grapes (Vitis complex) through immature seed culture and subsequent embryo culture. J Fac Agric Kyushu Univ. 2003;48:51-57.

4. Guo WW, Deng XX, Yi HL. Somatic hybrids between navel orange (Citrus sinensis) and grapefruit ( $C$. paradisi) for seedless triploid breeding. Euphytica. 2000;116:281-285. https://doi.org/10.1023/A:1004031621777

5. van Tuyl JM, Arens P. Lilium: Breeding history of the modern cultivar assortment. Acta Hortic. 2011;900:223-230. https://doi.org/10.17660/ActaHortic.2011.900.27

6. Marasek-Ciolakowska A, Xie SL, Arens P, van Tuyl JM. Ploidy manipulation and introgression breeding in Darwin hybrid tulips. Euphytica. 2014;198:389-400. https://doi.org/10.1007/s10681-0141115-3

7. Ramsey J, Schemske DW. Pathways, mechanisms, and rates of polyploid formation in flowering plants. Ann Rev Ecol Sys. 1998;29:467-501. https://doi.org/10.1146/annurev.ecolsys.29.1.467

8. Husband BC. The role of triploid hybrids in the evolutionary dynamics of mixed-ploidy populations. Biol J Linn Soc. 2004;82:537-546. https://doi.org/10.1111/j.1095-8312.2004.00339.x 
9. Harlan JR, deWet JMJ. On Ö. Winge and a prayer: the origins of polyploidy. Bot Rev. 1975;41:361390. https://doi.org/10.1007/BF02860830

10. Brandham PE. Inter-embryo competition in the progeny of autotriploid Aloineae (Liliaceae). Genetica. 1982;59:29-42. https://doi.org/10.1007/BF00130812

11. Lim KB, Ramanna MS, de Jong JH, Jacobsen E, van Tuyl JM. Indeterminate meiotic restitution (IMR): a novel type of meiotic nuclear restitution mechanism detected in interspecific lily hybrids by GISH. Theor Appl Genet. 2001;103:219-230. https://doi.org/10.1007/s001220100638

12. Lim KB, Gonzalez RB, Zhou SJ, Ramanna MS, van Tuyl JM. Meiotic polyploidization with homoeologous recombination induced by caffeine treatment in interspecific lily hybrids. Korean $\mathrm{J}$ Genet. 2005;27:219-226.

13. Lim KB, Ramanna MS, van Tuyl J. Comparison of homoeologous recombination frequency between mitotic and meiotic polyploidization in $\mathrm{BC}_{1}$ progeny of interspecific lily hybrids. Acta Hortic. 2001; 552: 65-72. https://doi.org/10.17660/ActaHortic.2001.552.6

14. Barba-Gonzalez R, Lim KB, Ramanna MS, Visser RGF, van Tuyl JM. Occurrence of $2 n$ gametes in the F1 hybrids of Oriental $\times$ Asiatic lilies (Lilium): relevance to intergenomic recombination and backcrossing. Euphytica. 2005;143:67-73. https://doi.org/10.1007/s10681-005-2657-1

15. Barba-Gonzalez R, Lokker AC, Lim KB, Ramanna MS, van Tuyl JM. Use of $2 n$ gametes for the production of sexual polyploids from sterile Oriental $\times$ Asiatic hybrids of lilies (Lilium). Theor App Genet. 2004;109:1125-1132. https://doi.org/10.1007/s00122-004-1739-0

16. Barba-Gonzalez R, Ramanna MS, Visser RGF, van Tuyl JM. Intergenomic recombination in F1 lily hybrids ( $L$ ilium) and its significance for genetic variation in the $\mathrm{BC}_{1}$ progenies as revealed by GISH and FISH. Genome. 2005;48:884-894. https://doi.org/10.1139/g05-057

17. Barba-Gonzalez R, Miller CT, Ramanna MS, van Tuyl JM. Nitrous oxide $\left(\mathrm{N}_{2} \mathrm{O}\right)$ induces $2 \mathrm{n}$ gametes in sterile F1 hybrids between Oriental $\times$ Asiatic lily (Lilium) hybrids and leads to intergenomic recombination. Euphytica. 2006;148:303-309. https://doi.org/10.1007/s10681-005-9032-0

18. Chung MY, Chung JD, Ramanna MS, van Tuyl JM, Lim KB. Production of polyploids and unreduced gametes in Lilium auratum $\times$ L. henryi hybrid. Int J Biol Sci 2013;9:693-701. https://doi.org/10.7150/ijbs.6427

19. Zhou SJ. Intergenomic recombination and introgression breeding in Longiflorum $\times$ Asiatic lilies. PhD thesis, The Netherlands: Wageningen University. 2007.

20. Zhou SJ, Ramanna MS, Visser RGF, van Tuyl JM. Genome composition of triploid lily cultivars derived from sexual polyploidization of Longiflorum $\times$ Asiatic hybrids (Lilium). Euphytica. 2008;160:207-215. https://doi.org/10.1007/s10681-007-9538-8

21. Zhou SJ, Ramanna MS, Visser RGF, van Tuyl JM. Analysis of the meiosis in the F1 hybrids of Longiflorum $\times$ Asiatic (LA) of lilies (Lilium) using genomic in situ hybridization. J Genet Genomics. 2008;35:687-695. https://doi.org/10.1016/S1673-8527(08)60091-0 
22. van Tuyl JM, Meijer B, van Diën MP. The use of oryzalin as an alternative for colchicine in in-vitro chromosome doubling of Lilium and Nerine. Acta Hortic. 1992;325:625-630.

https://doi.org/10.17660/ActaHortic.1992.325.88

23. Zhang XX, Ren GL, Li KH, Zhou GX, Zhou SJ. Genomic variation of new cultivars selected from distant hybridization in Lilium. Plant Breed. 2012;131:227-230. https://doi.org/10.1111/j.14390523.2011.01906.x

24. Zhou SJ, Li KH, Zhou GX. Analysis of endosperm development of allotriploid $\times$ diploid/tetraploid crosses in Lilium. Euphytica. 2012;184:401-412. https://doi.org/10.1007/s10681-011-0609-5

25. Zhou SJ, Yuan GL, Xu P, Gong HX. Study on lily introgression breeding using allotriploids as maternal parents in interploid hybridizations. Breed Sci. 2014;64:97-102. https://doi.org/10.1270/jsbbs.64.97

26. Zhou SJ, Zhou GX, Li KH. Euploid endosperm of triploid $\times$ diploid/tetraploid crosses results in aneuploid embryo survival in Lilium. Hortscience. 2011;46:558-562. https://doi.org/10.21273/HORTSCI.46.4.558

27. Mercier R, Mézard C, Jenczewski E, Macaisne N, Grelon M. The Molecular Biology of Meiosis in Plants. Annu Rev Plant Biol. 2015;66:297-327. https://doi.org/10.1146/annurev-arplant-050213035923

28. Zhang XQ, Cao QZ, Zhou P, Jia GX. Meiotic chromosome behavior of the male-fertile allotriploid lily cultivar 'Cocossa'. Plant Cell Reports. 2017;36:1641-1653. https://doi.org/10.1007/s00299-017-21806

29. Fenech M, Kirsch-Volders M, Natarajan AT, Surralles J, Crott JW, Parry J, Norppa H, Eastmond DA, Tucker JD, Thomas P. Molecular mechanisms of micronucleus, nucleoplasmic bridge and nuclear bud formation in mammalian and human cells. Mutagenesis. 2011;26:125-132. https://doi.org/10.1093/mutage/geq052

30. Asbury CL. Anaphase A: disassembling microtubules move chromosomes toward spindle poles. Biology. 2017;6:15. https://doi.org/10.3390/biology6010015

31. Simunić J, Tolić IM. Meiotic Spindle Has a Soft Spot. Dev Cell. 2019;49:159160.https://doi.org/10.1016/j.devcel.2019.04.004

32. Maheshwari P. The angiosperm embryo sac. The Bot Rev. 1948;14:1-56. https://doi.org/10.1007/BF02861693

33. Xi ML, van Tuyl JM, Arens P. GISH analyzed progenies generated from allotriploid lilies as female parent. Sci Hortic. 2015;183:130-135. https://doi.org/10.1016/j.scienta.2014.12.022

34. Natenapit J, Taketa S, Narumi T, Fukai S. Crossing of allotriploid LLO hybrid and Asiatic lilies (Lilium). Hortic Environ and Biote. 2010;51:426-430.

35. Köhler C, Weinhofer-Molisch I. Mechanisms and evolution of genomic imprinting in plants. Heredity. 2010;105:57-63. https://doi.org/10.1038/hdy.2009.176

36. Scott RJ, Spielman M, Bailey J, Dickinson HG. Parent-of-origin effects on seed development in Arabidopsis thaliana. Development. 1998;125:3329-3341. 
37. Okazaki K, Nishimura M. Ploidy of progenies in crosses between diploid, triploid and tetraploid in tulip. Acta Hortic 2000;522:127-134. https://doi.org/10.17660/ActaHortic.2000.522.13

38. Xing GM, Qu LW, Zhang W, Zhang YQ, Yuan XF, Lei JJ. Study on interspecific hybridization between tulip cultivars and wild species native to China. Euphytica. 2020;216:1-

17.https://doi.org/10.1007/s10681-020-02594-x

39. Xu P. Investigation on ploidy levels of Tulip cultivars and analysis of their interspecies crosses. MsD thesis, China: Zhejiang University. 2014.

40. Otto SP, Whitton J. Polyploid incidence and evolution. Annu Rev Genet. 2000;34:401-437. https://doi.org/10.1146/ANNUREV.GENET.34.1.401

41. Rieseberg LH, Willis JH. Plant speciation. Science. 2007;317:910-914. https://doi.org/10.1126/science. 1137729

42. Ramsey J, Schemske DW. Neopolyploidy in flowering plants. Ann Rev Ecol Sys. 2002;33:589639.https://doi.org/10.1146/ANNUREV.ECOLSYS.33.010802.150437

43. Leitch I, Johnston E, Pellicer J, Hidalgo O, Bennett M. Angiosperm DNA C-values database (release 9.0, Apr 2019). 2019. https://cvalues.science.kew.org/.Accessed 26 August 2020.

44. Lim KB, Ramanna MS, Jacobsen $E$, van Tuyl J,. Evaluation of $B C_{2}$ progenies derived from $3 x-2 x$ and $3 x-4 x$ crosses of Lilium hybrids: a GISH analysis. Theor Appl Genet. 2003;106:568574.https://doi.org/10.1007/s00122-002-1070-6

45. Khan N, Zhou SJ, Ramanna MS, Arens P, Herrera J, Visser RGF, van Tuyl JM. Potential for analytic breeding in allopolyploids: an illustration from Longiflorum $\times$ Asiatic hybrid lilies (Lilium). Euphytica. 2009;166:399-409. https://doi.org/10.1007/s10681-008-9824-0

46. Wang Q, Wang JM, Zhang YY, Zhang Y, Xu SC, Lu YM. The application of fluorescence in situ hybridization in different ploidy levels cross-breeding of lily. Plos One. 2015;10:e126899. https://doi.org/10.1371/journal.pone.0126899

47. Suzuki T, Yamagishi M. Aneuploids without bulbils segregated in F1 hybrids derived from triploid Lilium lancifolium and diploid L. leichtlinii crosses. Hortic J. 2016;85:224-231. https://doi.org/10.2503/hortj.MI-089

48. Barba-Gonzalez R, van Silfhout AA, Visser RGF, Ramanna MS, van Tuyl JM. Progenies of allotriploids of Oriental × Asiatic lilies (Lilium) examined by GISH analysis. Euphytica. 2006;151:243-250. https://doi.org/10.1007/s10681-006-9148-x

49. Luo JR, Ramanna M, Arens P, Niu LX, van Tuyl JM. GISH analyses of backcross progenies of two Lilium species hybrids and their relevance to breeding. J Hortic Sci Biotechnol. 2012;87:654-660. https://doi.org/10.1080/14620316.2012.11512926

50. Xie SL, Ramanna MS, van Tuyl JM. Simultaneous identification of three different genomes in Lilium hybrids through multicolour GISH. Acta hortic. 2010;855:299304.https://doi.org/10.17660/ActaHortic.2010.855.45 
51. Lim KB, Chung JD, van Kronenburg BC, Ramanna MS, de Jong JH, van Tuyl JM. Introgression of Lilium rubellum Baker chromosomes into $L$. longiflorum Thunb.: a genome painting study of the F1 hybrid, BC1 and BC2 progenies. Chromosome Res. 2000;8:119-

125.https://doi.org/10.1023/a:1009290418889

52. Park SM, Wakana A, Kim JH, Jeong CS. Male and female fertility in triploid grapes (Vitis complex) with special reference to the production of aneuploid plants. Vitis-Geilweilerhof 2002;41:11-20.

53. Ozaki Y, Narikiyo K, Fujita C, Okubo H. Ploidy variation of progenies from intra- and inter-ploidy crosses with regard to trisomic production in asparagus (Asparagus officinalis L.). Sex Plant Reprod. 2004;17:157-164. https://doi.org/10.1007/s00497-004-0229-5

54. Peckert T, Chrtek J. Mating interactions between coexisting dipoloid, triploid and tetraploid cytotypes of Hieracium Echioides (Asteraceae). Folia Geobot. 2006;41:323-

334.https://doi.org/10.1007/BF02904945

55. Diao WP, Bao SY, Jiang B, Cui L, Chen JF. Primary trisomics obtained from autotriploid by diploid reciprocal crosses in cucumber. Sex Plant Reprod. 2009;22:45-51. https://doi.org/10.1007/s00497008-0090-z

56. Fang L, Yang B, Zhang WN, Xin HY, Gao TT, Shi JS, Guo J, Xi ML. The ploidy level investigation and FISH analysis of the progenies from allotriploid Lilium as male. Mol Plant Breed. 2014;12:138-143.(In Chinese with an English abstract)

57. Ren YR, Zhang CH, Shen EQ, Xuan SX, Shen SX. Chromosome number identification and generation of monosomic alien addition line in the triploid interspecies hybrid of flowering Chinese cabbageChinese kale. Acta Horticulturae Sinica. 2010;37:213-220.(In Chinese with an English abstract)

58. Vu HQ, Yoshimatsu Y, Khrustaleva LI, Yamauchi N, Shigyo M. Alien genes introgression and development of alien monosomic addition lines from a threatened species, Allium roylei Stearn, to Allium cepa L. Theor Appl Genet. 2012;124:1241-1257. https://doi.org/10.1007/s00122-011-1783-5

59. Lv GH, Tang QL, Guo GJ, Chen JJ, Rong TZ. Study on Morphologic and Cytogenetic Characterization of Fertile Triploid from Zea may $\times$ Zea perennis. Journal of Plant Genetic Resources 2015;16:11521156. https://doi.org/10.13430/j.cnki.Jpgr.2015.06.003 (In Chinese with an English abstract)

60. Cao QZ, Lian YQ, Wang LJ, Zhang Q, Zhao YQ, Jia GX, He HB. Physical mapping of 45S rDNA loci in Lilium OT hybrids and interspecific hybrids with Lilium regale. Sci Hortic. 2019;252:4854.https://doi.org/10.1016/j.scienta.2019.03.035

61. Ji NZ, Feng H, Li NX, Zhao HE, Zhao SW. Application in Rose Hybrid and Progeny Ploidy Analysis of Triploid Chinese Old Garden Rose. Mol Plant Breed. 2019;17:6424-6433. (In Chinese with an English abstract)

62. Xiao KZ, Zheng W, Zeng J, Wu LK, Cui LM, Liu YM, Yang YX, Zhou SJ. Analysis of abnormal meiosis and progenies of an odd-allotetraploid Lilium 'Honesty'. Sci Hortic. 2019;253:316321.https://doi.org/10.1016/j.scienta.2019.04.012

63. Yang YX, Zheng W, Xiao KZ, Wu LK, Zeng J, Zhou SJ. Transcriptome analysis reveals the different compatibility between LAAA × AA and LAAA × LL in Lilium. Breed Sci. 2019;69:297-307. 
https://doi.org/10.1270/jsbbs.18147

Figures

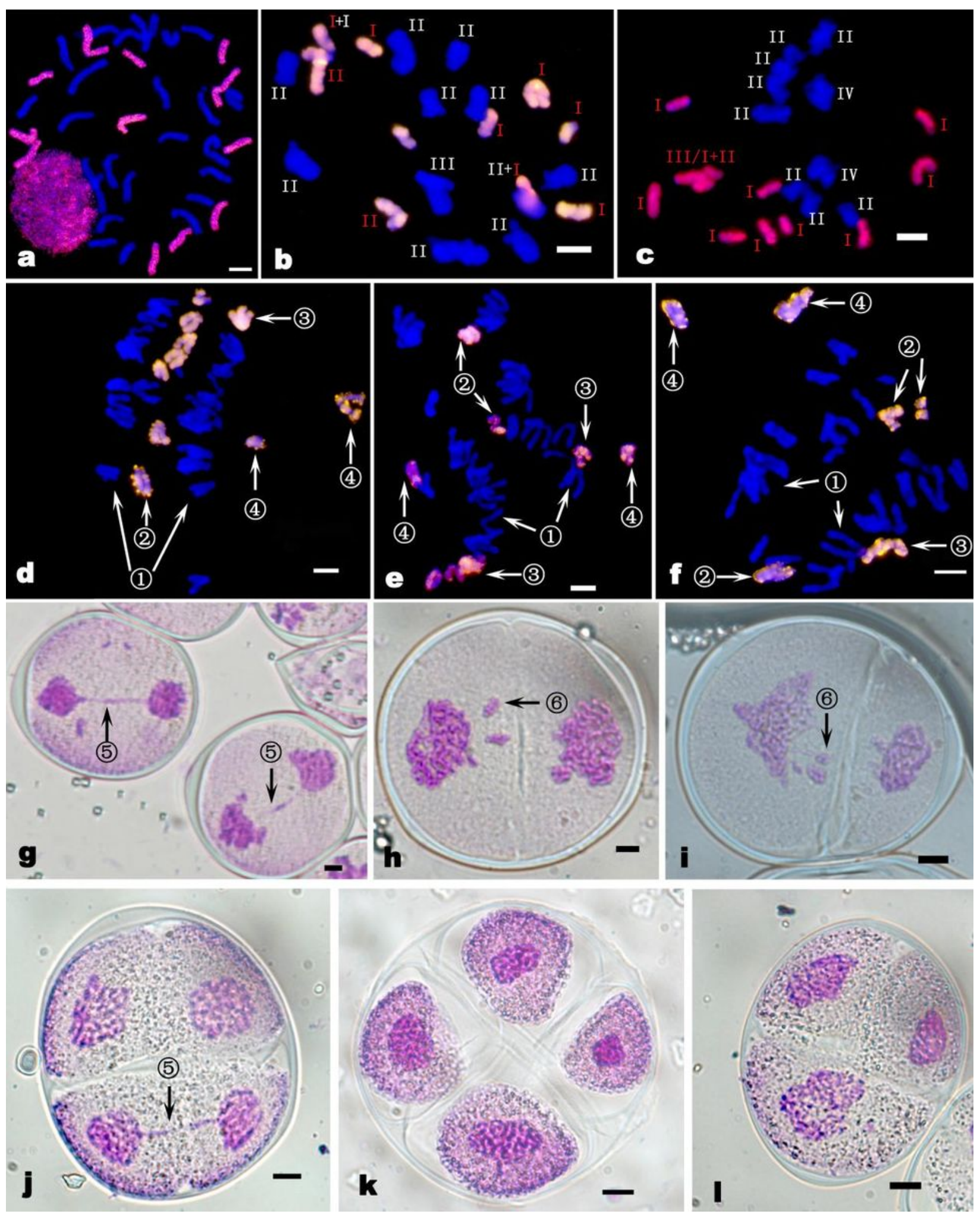

Figure 1 
The microsporogenesis of 'Triumphator'. a. the genome composition of 'Triumphator'; b c. metaphase l; d f. anaphase l; g i. telophase l; j l. telophase II (j and k: tetrad, l: triad). The O-chromosomes are red and L-chromosomes are blue. "I", "II", "III" and "IV" means of univalent, bivalent, trivalent, and tetravalent, respectively. \. the separated bivalents (half-bivalents); $\gtrsim$. the univalents, two sides of which are attached

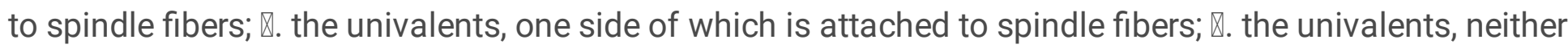

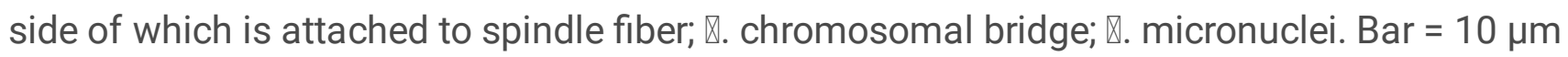

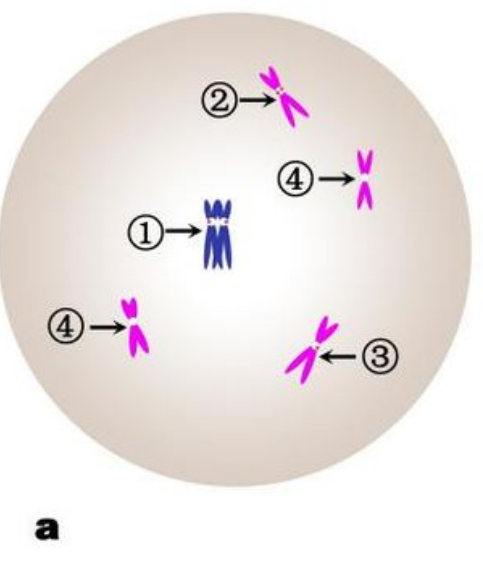

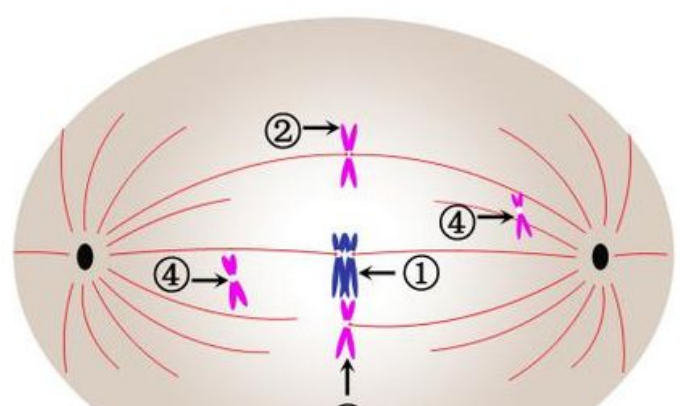

(3)

b

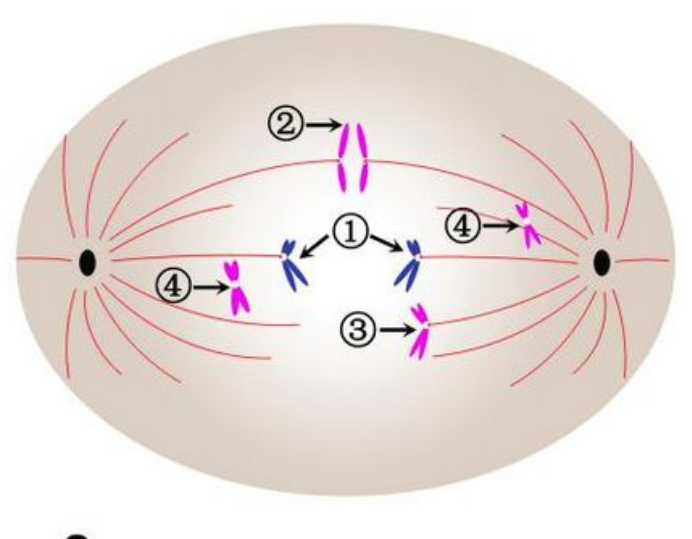

c

\section{Figure 2}

The ideogram of abnormal behavior of chromosomes of LLO lily. a. the metaphase I when spindle fibers are vertical to the chromosome slide; $b$. the metaphase I when spindle fibers are parallel to the chromosome slide; $\mathrm{c}$. the anaphase I when spindle fibers are parallel to the chromosome slide. $\mathbb{\nabla}$. the bivalents at metaphase I become half-bivalents at anaphase I; $\Downarrow$. the univalents, two sides of which are attached to spindle fibers; $\Downarrow$. the univalents, one side of which is attached to spindle fibers; $\mathbb{\text { }}$. the univalents, neither side of which is attached to spindle fibers

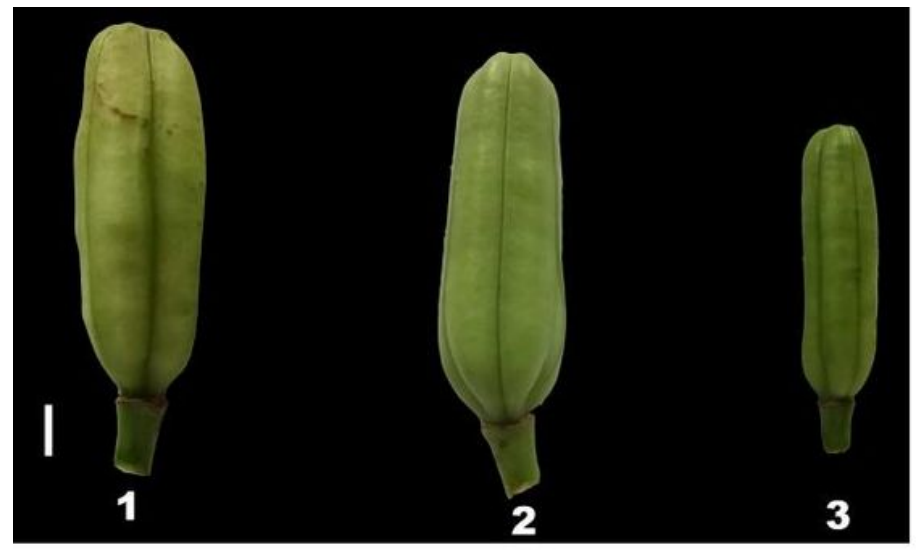

a
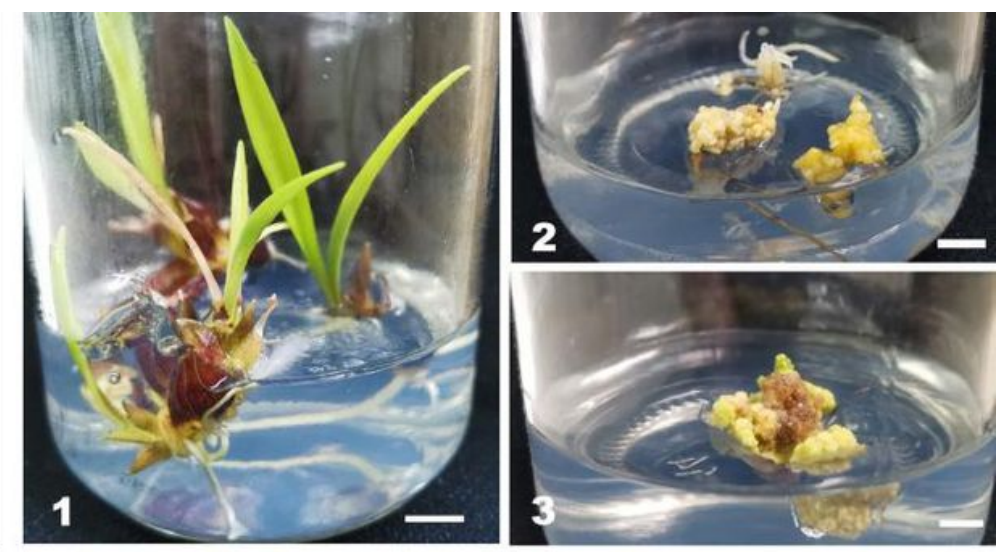

\section{Figure 3}

a. The fruits of different crosses. b. Ovule culture from crosses 1, 2, and 3 of Table 2. Bar $=1 \mathrm{~cm}$ 


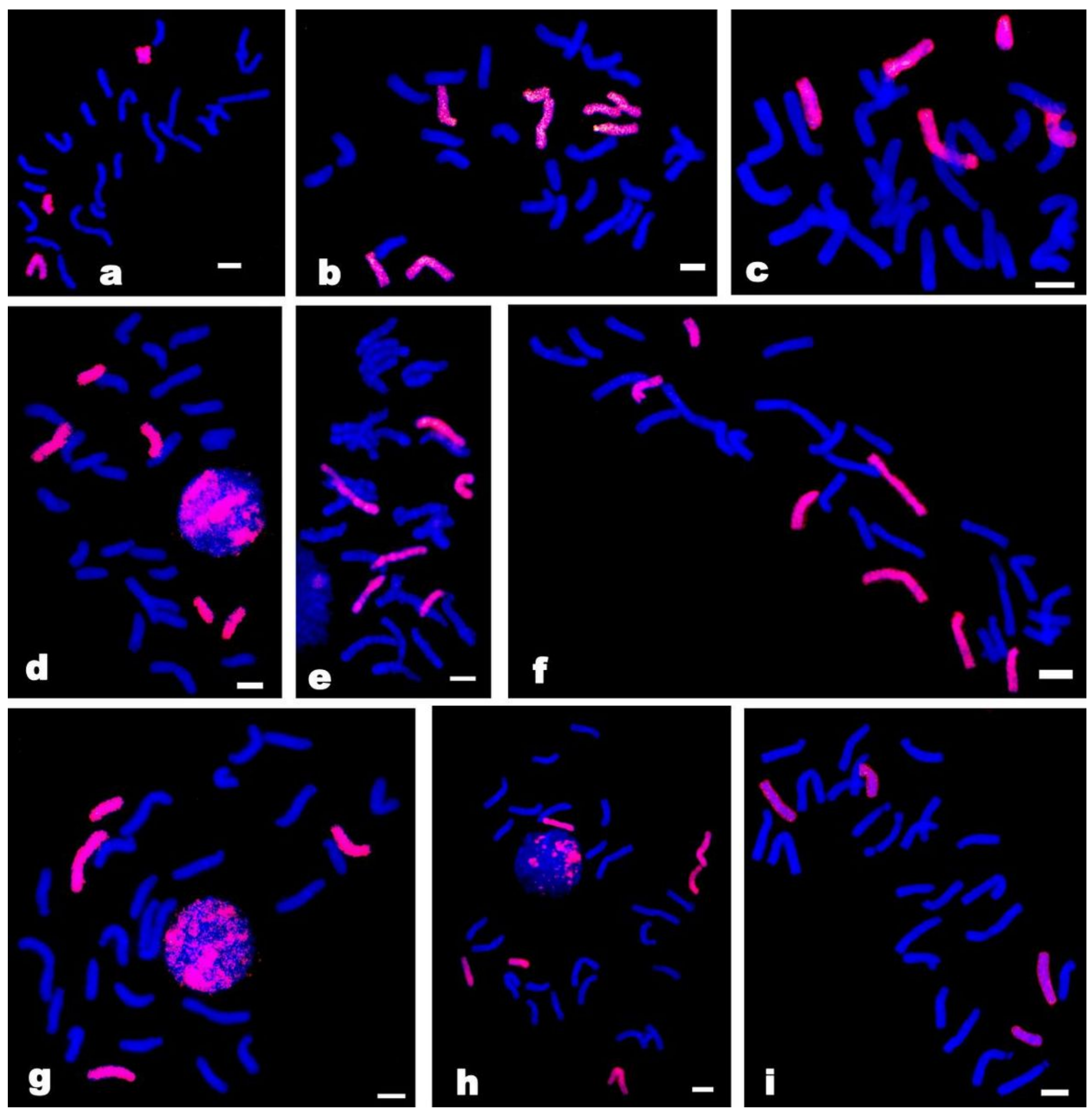

Figure 4

GISH analysis on the mitotic chromosomes of seedlings of LLO $\times$ LL. a i are corresponding to the "Seedling code", 1, 2, 4, 5, 6, 7, 10 , 11, and 12, in Table 3 respectively. Bar $=10 \mu \mathrm{m}$ 

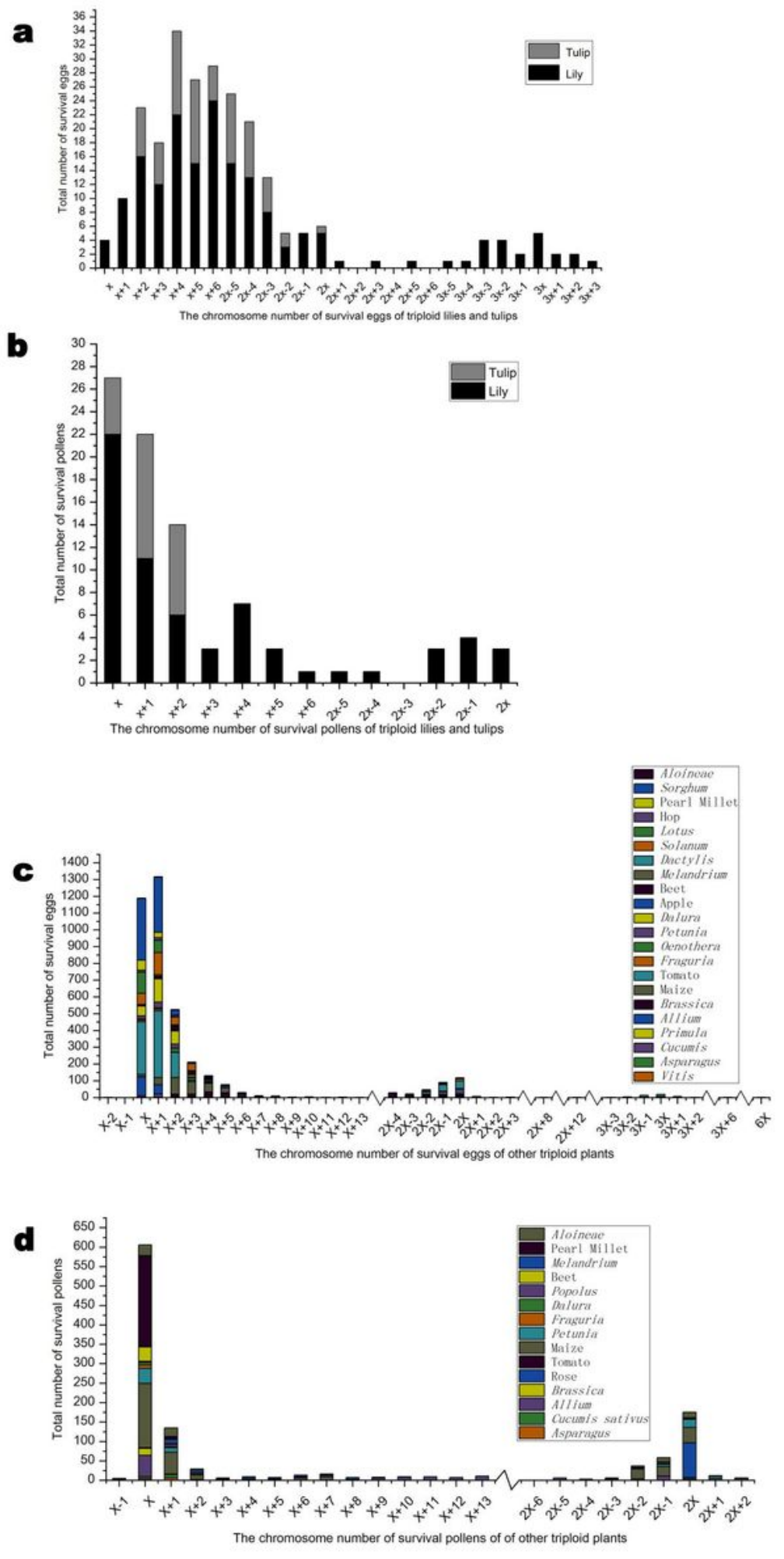

\section{Figure 5}

The frequency of the survival gametes with different chromosome numbers. a. the survival eggs of triploid lilies and tulips with Fritillaria embryo sacs are predominantly aneuploid; $b$. the survival pollen grains of triploid lilies and tulips are predominantly euploid $(n=x)$ and near euploid $(n=x+1$ and $n=x+$ $2)$; c. the survival eggs of triploid plants with Polygonum embryo sacs are predominantly euploid $(n=x)$ 


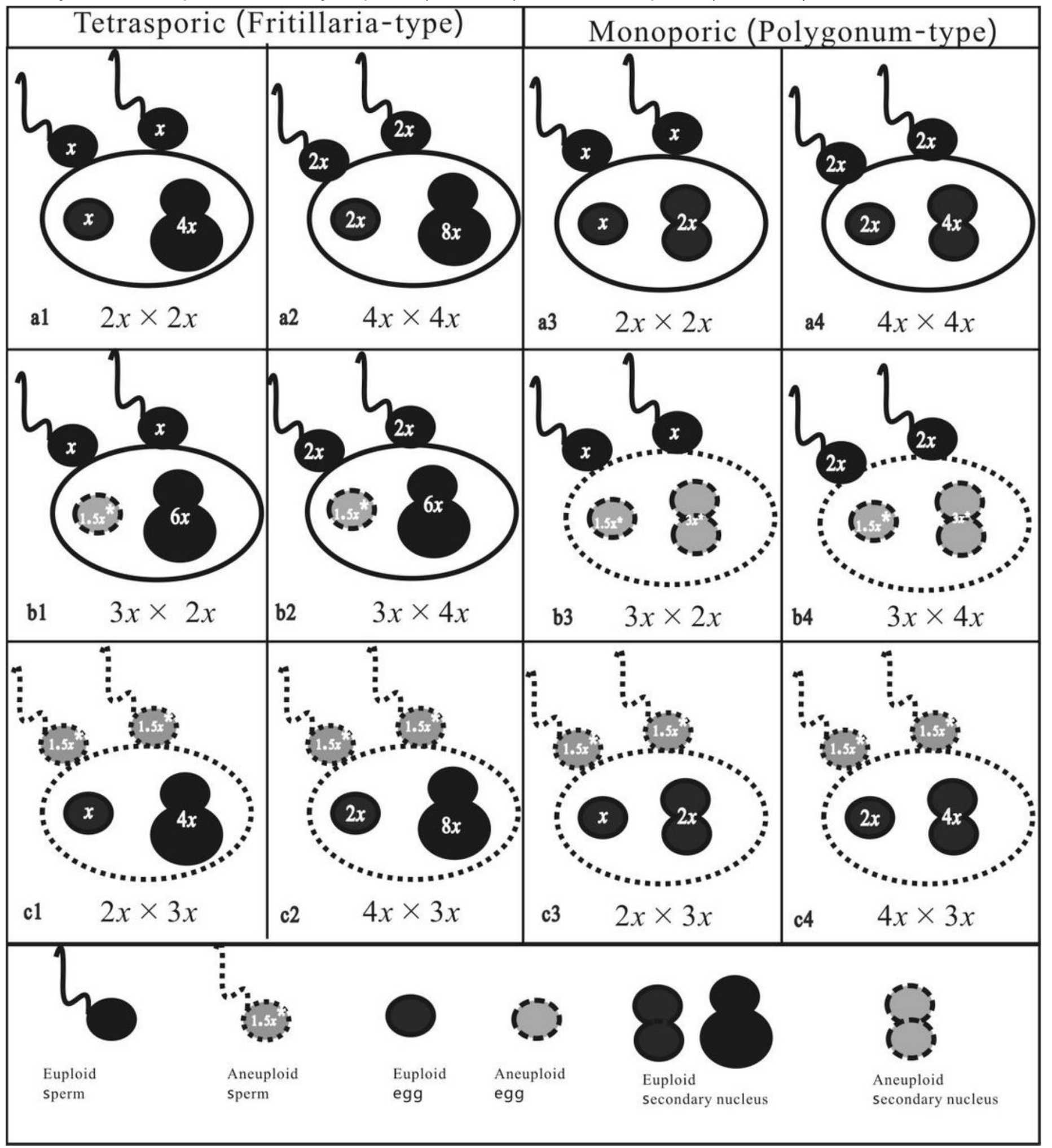

Figure 6

Ideogram of difference of embryo sacs of $3 x \times 2 x / 4 x$ and $2 x / 4 x \times 3 x$ between Fritillaria-type plants and Polygonum-type plants after double fertilization referred to Zhou et al. [26]. a1, a 2, a3 and a4 are normal crosses and both their endosperm and embryos are euploid; b1 and b2 are triploid lily as female, embryos 
are aneuploid while endosperm euploid, so euploid endosperm make the aneuploid embryos survival; b3, b4, c1, c2, c3, and c4, all have both aneuploid embryos and aneuploid endosperm, so euploid or near euploid gametes are usually survived though triploids usually produce aneuploid gametes 